\title{
1968: YEAR OF TRIAL, YEAR OF LOSS
}

VOLUME 11, NO. 12 DECEMBER 1968

WORLDVIEW is published monthly [except for a combined July-August issue] by the Council on Religion and International Affairs. Subscription $\$ 4.00$ for one year; $\$ 7.00$ for two years; $\$ 9.00$ for three years.

Address: 170 East 64th Street, New York, New York 10021. TE 8-4120

\section{EDITORIAL BOARD}

James Finn, Editor

John R. Inman

A. William Loos

Editoria! Assistant, Susan Woolfson

\section{CONTENTS}

\section{In the Magazines \\ 1968, Year of Trial, Year of Loss Editorial \\ The Right to Know, Right to Withhold, and Right to Lie, II William J. Barnds}

Violence and the Peace Movement: The Relevance of Camus Robert Pickus

From the U.N.:

Fact and Fiction John R. Inman

Election 1968, and Beyond Other Voices

Current Reading

Readers are reminded that worldview welcomes correspondence. Letters may be specific comments on articles in recent issues or general dis. letters to 500 words.

Opinions expressed in worldview are those of the authors, and not necessarily of the Council on Religion and International Affairs. Copyright
1968 Council on Religion and International Affairs.
In terms of our political and social life, 1968 was a disconcerting and disordered year. In the United States, confrontation, riots and assassination changed the direction that normal political procedures would have afforded us. There is now, between the election of Richard Nixon and his inauguration, a lull in some of the more vigorous political demonstrations, but there are enough disturbances on campuses and in cities across the coumtry to remind us that we have not yet found our way through the general haze of confusion and dissension and that we have not yet found an adaquate response to the tough questions that recent years have precipitated into national consciousness.

In 1968, the political procedures on which we have normally depended for the governance of our society were severely challenged. In many instances the challenges revealed the structures to be archaic, rigid and unresponsive, mechanisms whose former utility had been transformed into present-day obstruction. More importantly, the challengers often extended their attack beyond the machinery of government to question the values which the society actually accepts and by which it lives. And here the issue remains - more disjointed than joined - on what these values are, who most accurately perceives them, what are the superior values which should and supposedly can replace them, how are these allegedly superior values to be made operative in our society.

Under attack, the existing political structures performed both better and worse than their critics and defenders alleged. The strong resistance to the policies of the Johnson Administration, particularly to the increasingly umpopular war in Vietnam, was surprisingly effective. It is unlikely that, without a solid if often frantic base of protest, Eugene McCarthy would have declared himself a candidate for the Presidency. Without the success that attended his entrance into the presidential contest it is unlikely that Robert Kennedy would also have entered. And without the concatenation of these events the withdrawal of President Johnson, long regarded as possible but unlikely, would not have occurred. The political system, thus, did prove more flexible, more responsive than its harshest crities have asserted.

But, ats more than the harshest erities pointed ont, the system then worked to present to the electorate a choice of presidential candidates none of whom strongly dissented from the Vietnam policy against which the most substantial political protest had been aimed. In these terms the political mechanisms did prove less responsive, less open than their most unyielding supporters have argued. 
The assassination of Martin Luther King, Jr. and of Robert Kennedy made evident, if not clear, the relations between political event and social values. In quite different ways, both men had become not only political agents but symbols for what large groupings of American citizens hoped for, aspired to. Their sudden removal from our national life leaves us poorer, although the ways in which they might have altered our future course are, today, only matters for speculation.

These sudden turns and reversals had their parallel in other parts of our institutional life, particularly in the universities. And as the year drew to an end, the kinds of issues raised by the riots, of which the upheaval at Columbia University is an exemplar, remained strung out. Again, the initial difficulty is not in answering the problems that have been raised but in discerning more clearly what the basic problems are. The fact that there is a multiplicity of organizations and individuals eager to tell us in sharp terms what they see as basic is not an answer but part of the problem.

-

But if Americans found themselves disturbed uneasy and dissatisfed at the state of the nation - usually placing the responsibility for that dissatisfaction on groups of which they are not members - other countries did not fare much better. England not only has to cope with a Labour government that becomes increasingly estranged from laboring people but with a leading politician whose racist warnings gain much support. In France General de Gaulle weathered another storm, the student revolution which Raymond Aron was content to put down as psychodrama, but the revolt and subsequent splintering of allegiances indicate that in France, too, there is a pervasive uneasiness. More important than the student revolution, however, was the flight of capital from France, the country which had so lately been putting a strain upon the gold reserves of the United States: Whether these events will bring France to a new understanding of itself and its position in relation to Europe and the great powers is uncertain, but they are incentives to

\section{CHANGE OF ADDRESS}

Because of the rapid increase in worldview subscriptions, there is presently a delay in processing requests for address changes. Please allow one month for changes to become effective. (And as much advance notice as possible would be most appreciated.) reconsider some of the General's formulations.

For Czechoslovakia and the suppression of much that tended to liberalize and humanize, disruption and dissatisfaction are clearly inappropriate descriptions. But neither does the term tragedy, which has so often been invoked in discussions about Czechoslovakia, seem appropriate to describe the very difficult circumstances through which it is struggling. And if Czechoslovakia has proved to be - as some have contended - the greatest boost NATO has received in recent years, the events in Greece have pushed in the opposite direction. The present dictatorial regime was given official recognition relatively early by the United States and, through the person of Admiral Horatio Rivero, NATO supported it more than indifferently, but other countries including Italy and the German Federal Republic have followed a quite different course. Greece, however stable and benign the present regime declares itself to be, remains a deeply troubled and troubling country.

\section{$\bullet$}

As troubling, as disturbing as they are, the events in Greece and in Czechoslovakia fall into recognizable patterns. Whether adequately or not, the foreign policies of the United States were prepared to cope with them. We do not have the same assurance about either the civil war in Nigeria, where the Biafrans are fighting but starving, or about the Middle East, where the ArabIsraeli confrontation is potentially so dangerous not only to the countries immediately involved, but to world peace.

One could, in a survey of civil and national affairs around the globe, find encouraging signs, problems that have been resolved and differences that have been amicably settled. But a survey that highlights only the troubled areas and the tinderboxes that seem to need only the spark of conflict to set them off should do more than simply discourage us. At the end of a year such as 1968 , such a survey should serve to remind us that the foreign policy of the United States does not turn on, cannot be fully discerned in, a single issue, even one as important as Vietnam.

The crisis mentality that has been so prominent in political discussions during 1968 is understandable, but it is not, over the long run, serviceable. 1968 has served to bring new persons and new minds into our political/social discussion, but the years ahead will be for them the years of testing.

J.F.

4 worldview 